\title{
The Current State of Instructional Materials Education: Aligning Policy, Standards, and Teacher Education Curriculum*
}

\author{
Serpil Tekir ${ }^{1}$ \\ Middle East Technical University
}

\author{
Hanife Akar ${ }^{2}$ \\ Middle East Technical University
}

\begin{abstract}
Effective use of instructional materials is stated as an important professional competence that foreign language teachers should have in the policy documents of Turkish Higher Education Council, and in the standards documents of Turkish Ministry of National Education. In spite of this emphasis on the policy and standards, beginning teachers continue to demonstrate low competence in instructional materials. This may result from limited instructional materials education that is potentially misaligned to teacher education policies and professional teaching standards. Accordingly, the purpose of this study is to analyze the alignment between teacher education policy, professional standards for teacher practice and preservice instructional materials course curriculum through a curriculum alignment methodology. The study concludes with a discussion on the current state of instructional materials education with implications for enhancing teacher preparation in this area and future research on materials education.
\end{abstract}

\section{Keywords}

Curriculum Alignment • Instructional Materials Education • Pre-service Teacher Education • Professional Teaching Standards • Teacher Competence • Teacher Education Policy

\footnotetext{
${ }^{1}$ Correspondence to: Serpil Tekir (PhD), Department of Basic English, Middle East Technical University, 06531 Ankara, Turkey. Email: stekir@metu.edu.tr

${ }^{2}$ Assoc. Prof. Dr. in Educational Sciences, Faculty of Education, Middle East Technical University 06800 Ankara, Turkey. Email: hanif@metu.edu.tr

Citation: Tekir, S., Akar, H. (2019). The Current State of Instructional Materials Education: Aligning Policy, Standards, and Teacher Education Curriculum. Educational Sciences: Theory \& Practice, 19(1), 22-40. 
About the core knowledge and skills that a teacher is required to have, teacher education policies, professional teaching standards and recent research all indicate that literacy and competence in instructional materials plays a central role (Caena, 2014; Kitao \& Kitao, 1997; Milli Eğitim Bakanlı̆̆ı [MEB], 2002, 2008, 2017; Shulman 1987; Yüksek Öğretim Kurumu [YÖK], 2005, 2018). Similarly, the two important agents in teacher education in Turkish context, the Ministry of National Education (MNE), and the Higher Education Council (HEC), mention competence in instructional materials as an important requirement. To develop preservice teachers' competence in instructional materials, teacher education programs utilize instructional materials courses. The problem is that although instructional materials education offered at preservice programs, EFL teachers demonstrate low instructional materials literacy levels and feel unprepared regarding instructional materials (Kızılaslan, 2011; Sali \& Keçik, 2018).

Limited preservice materials education that is theory-laden, disconnected from teachers' daily practices and potentially misaligned to current materials policies and standards may contribute to this low competence levels. As such, there is lack of evidence to suggest that the content of preservice instructional materials courses are meeting the instructional materials literacy needs of teacher candidates or that they align with policies and standards aimed at developing teacher competence in instructional materials. Therefore, the alignment between instructional materials course curriculum and the policy and standards for teacher competence in instructional materials has yet to be examined. Thus, the current research is significant as it would serve to identify gaps in teacher preparation and guide improvements in teacher education syllabi in courses pertaining pre-service teachers' use of instructional materials.

This study examined how national directives translate into teacher education programs by analyzing the alignment of preservice instructional materials education curriculum with the explicit policies and standards across two alignment dimensions (i.e., content focus and depth of competence). The following research questions guided our investigation:

1. What is the content focus and depth of competence represented in teacher education policy documents, teaching standards, and instructional materials course syllabi learning expectations?

2. What is the degree and nature of alignment between policy and standards documents, and instructional materials course learning expectations as related to the two alignment dimensions?

A curriculum alignment methodology was used to respond to these research questions. By examining the alignment between policy and practice, this research may emphasise the delicacy of policy implementation in centralized education systems and the significance of well-aligned teacher education programs for adequately preparing teacher candidates for their future careers, which will for sure affect the quality of education at schools in the long run. All these factors contribute to the significance of the study.

\section{Literature}

\section{Alignment}

The concept of alignment as stated in some resources has various definitions in the literature. Different researchers offer different definitions of the term. While some consider it as the match of topics between subject 
areas and grades (Newmann, Smith, Allensworth, and Bryk, 2001), some regard it as an organizational issue (Bryk, Lee, and Holland, 1993; Coleman, Hoffer, and Kilgore, 1982). Still some other researchers use the term to characterize the agreement among components of the instructional system (Anderson, 2002; Biggs, 1999; Cotton and Savard, 1982; English, 1992; Fuhrman, 1993; Smith \& O’Day, 1991).

In this research, the alignment means the alignment of the EFL preservice instructional materials education curriculum to the explicit policies and professional standards as stated by Drake and Burns (2004). In other words, alignment in this study refers to the match between the intended outcomes of the undergraduate level course offered by a teacher education program and the explicit policies and standards for the profession.

\section{Alignment in Teacher Education}

There is a global idea adopted by politicians and educators claiming that the students' success relies too much on the teacher, and to improve teacher education, they concentrate on the characteristics of teacher education. The result of their observations puts forth alignment problems like separate courses that are not related with each other, a gap between clinical work and courses and the absence of vision of teaching and learning. Zeichner and Gore (1990) claimed that all teacher education programs having such alignment problems are regarded as comparatively inadequate as change agents affecting the way new teachers are educated. Likewise, Britzman (1990) suggested that if teacher education programs lack alignment, teacher candidates may think that what they have learned in the field does not match with or even worse disproves what they have learned in their university courses. This contradiction may lead to new teachers' difficulty in learning new practices, trying changes, or adapting a professional understanding of teaching and learning (Guyton \& McIntyre, 1990; Zeichner \& Liston, 1996; Zeichner \& Tabachnik, 1981).

With such a concern, Darling-Hammond (2000, 2006), Howey and Zimpher (1989) and Grossman, Hammerness, McDonald, and Ronfeldt (2008) studied multiple programs and concluded that the alignment is crucial for the success of teacher education programs. They also made some suggested for teacher education programs to be more aligned such as having aligned core ideas and learning opportunities not only in course work but also in clinical work, offering learning experiences in a well-structured way with a direct aim to educate teacher candidates towards a set of purpose, which will enable them to be well equipped for their future career.

\section{Previous Research on Alignment}

Of the few researchers studying alignment in teacher education, Grossman and friends (2008) studied if certain structural characteristics of teacher education programs affect how student teachers perceive program alignment. At the end of their research, they found that aligned programs has a number of features such as a shared vision regarding teaching and learning, conceptual and logistical organization of coursework around those aims and goals, and courses and clinical experiences designed to support, reinforce, and reflect those shared ideas. However, they concluded that the relationship between such features of teacher education and student perceptions of alignment is not a causal one. 
Another researcher, Tatto (2006) searched the relation between program alignment and student teachers' beliefs and values about the teaching profession, and she suggested that in cases where faculty espoused more coherent views around professional norms, student teachers tended to show more definite movement toward developing views that were in turn congruent with those espoused by the faculty.

Similarly, Heggen and Therum (1996) examined the impact of coherent professional education on students' dedication to and identification with a profession, and claimed that when students experience a clear relationship between schoolwork and fieldwork and satisfactory interactions with peers and supervisors, it is more likely that teacher education contributes to their development of motivation and professional identity.

Russell, McPherson and Martin (2001) analyzed the defects of conventional programs and considered some features of alternative conceptions such as collaboration between school and university. They reported that to boost how student teachers perceive alignment of their learning experiences, some measures should be taken such as having links between field faculty and program faculty by considering the characteristics of coursework and fieldwork, selecting the cooperating teachers with a similar vision with program, increasing the amount of time that they are in the institution and having more regular supervisor monitoring of fieldwork.

Different from other researches, Hammerness (2012) focused on the struggle of a teacher education program to become more coherent. At the end of her study, she pointed out that by developing a vision around which the program could be redesigned, and using this vision clearly and consistently across key program documents and having all program staff and clinical faculty (such as cooperating teachers and supervisors) adopt the same vision, the program succeeded in developing some internal, external, structural and conceptual coherence.

In a different way, DeLuca and Bellara (2013) examined the alignment of expectations in the preservice assessment course syllabi to the teacher education policies and teacher standards for educational evaluation and found that there is high degree of alignment across evaluative standards, policies, and course learning expectations, which contributes to the success of the program in training teacher candidates for their future careers.

\section{Studies on the Foreign Language Teacher Education Program}

There are several studies conducted on the foreign language teacher education program, which is the case program of this particular research. Reviewing these studies will be helpful in both understanding the context of the study and comparing and contrasting the results of the current study.

One of the studies evaluating the case program belongs to Seferoğlu (2006). She conducted a qualitative case study on senior year students to explore their reflections on the methodology and practice components of the pre-service teacher-training program, and she concluded that preservice teacher think that the link between course materials and practical application in real classrooms is not strong. They also criticized the program for not providing them enough opportunities for microteaching and practice teaching.

Another researcher, Gürbüz (2006), focused only on the Practice Teaching course to investigate the strengths and weaknesses of the fourth-year student teachers during their practicum experience. Her study indicated that preservice teachers feel strong in materials preparation, motivation and enthusiasm, creating a relaxed and a 
pleasant classroom atmosphere, and establishing good rapport with students. However, the participants explained lacking competence in monitoring group work, giving feedback for correction and using voice for effective instruction.

In her program evaluation study, Şall1-Çopur (2008) aimed to explore the extent that preservice teachers perceive themselves competent as EFL teachers and to what extent they find the FLE program components successful in helping them gain these competencies. She also reached the employers of FLE graduates to explore how competent these graduates are viewed and how successful the program is considered in serving its graduates gain teacher competencies. The findings revealed that the FLE graduates perceived themselves competent in most of HEC's competence areas, while there still is a need for improvement for competencies of language knowledge, spoken use of English, classroom management, assessment and instruction.

Coşkun and Daloğlu (2010) evaluated the same program from teachers' and students' perspectives to reveal the components of the program that need improvement. At the end of their study, they found that courses related to materials development seem to be the most favoured courses by both preservice teachers and instructors. Most preservice teachers made positive comments on these courses by saying they learnt how to use, adapt and develop language-teaching materials thanks to these courses. However, about the areas to be improved participant groups did not agree. While instructors believed that the program did not suffice to improve preservice teachers' linguistic competence, preservice teachers thought that the pedagogic side of the program needs to be improved.

\section{Methodology}

\section{Alignment Methodology}

This study used a curriculum alignment "Methodology based on Porter's alignment analysis" (Porter, 2002), to fulfill its purpose to examine the congruence between policies and standards for teacher competence in instructional materials and preservice instructional materials course curriculum.

To examine the congruence, we created an analytic alignment approach that used a moderate complexity approach. In our approach, we drew on two alignment dimensions: a) categorical concurrence and b) depth of competence because while coding for the expected competence areas in the documents, it was seen that the standards related to each competence category seemed to express a different level of complexity or demand from teachers. Therefore, we based upon the assumption that competences set by explicit documents required a different level of expectation, or depth of competence from the teachers. The levels used in this phase reflect the level of work teachers are required to perform in order for the competence to be considered acceptable. Just like in Bloom's Taxonomy (Bloom, 1956), and Webb' Depth of Knowledge (Webb, 1997) the levels in this study describe the kind of action required starting from the simplest to the most complex cognitive process and behaviour, which is also compatible with Porter's alignment analysis, that requires two criteria or in other words dimensions for analysis to be used for alignment calculation (Porter, 2002). 
Congruent with policy-based research, we assert that initially examining policy and curricular intentions provides a necessary basis for further analysis on enactment. We also assert that the use of course syllabi in this study provides a basis for drawing inferences on instructional materials course intentions (i.e., intended curricula) but fully recognize that this data source does not enable inferences to be made about course enactment or student learning in instructional materials courses.

\section{Teacher Competences Expected in Policy and Standards Documents}

The Higher Education Council and Ministry of National Education are the two institutions responsible for making macro level decisions on teacher education and recruitment in Turkey. In order to offer high quality teacher training across the country these two superior bodies make policies on teacher education and set standards for the teaching profession.

HEC initiated a new teacher education program in 2018 and in this latest policy document, HEC gives the list of must courses and defines the course contents for teacher education institutions. Studying the contents of the materials courses, it is clear that HEC expects teacher candidates to be able to develop and use materials like songs, games and visuals to teach young learners, know the features of quality materials and evaluate if course books are appropriate to learners, their language learning objectives, and the classroom context and adapt them accordingly (YÖK, 2018). HEC also requires teacher candidates to know the features and procedures of digital materials, develop computer assisted teaching materials through educational technologies and evaluate computer assisted teaching materials.

Similarly, the Ministry of National Education, the chief teacher recruiting body in Turkey, identified task definitions of teachers to set clear objectives for their personal and professional development. These definitions of General Competencies of Teaching Profession were updated in 2017. In this new policy document three interrelated competency domains, namely professional knowledge, professional skills, and attitudes and values were listed. These main domains include 11 competencies and 65 indicators related to the competencies (MEB, 2017). According to the new competence framework, a professional teacher is expected to be able to prepare appropriate teaching materials and builds healthy and safe learning environments, where effective learning can be achieved for all students. She or he needs to prepare teaching materials suitable to learning outcomes of the curriculum and be able to make use appropriate tools, equipment and materials effectively in the teaching and learning process.

As it is clear in the policy document of HEC and standards documents of MNE, instructional material is one of the required competence areas. To meet this requirement, individual teacher education institutions offer an explicit course on instructional materials. The majority of explicit material courses offered across preservice programs are one semester in duration and serve to introduce instructional materials used in EFL context.

\section{The Teacher Education Program and the Instructional Materials Education}

The current study was carried at an undergraduate foreign language teacher education program at a state university in central Turkey. The program aims to make teacher candidates fully qualified teachers of English 
in primary, secondary and tertiary educational institutions. Within this purpose, teacher candidates are provided with a solid foundation in the English language, literature, linguistics, methodology and educational sciences.

The Materials Adaptation and Development course, which is within the methodology component of the program, is offered as a continuation of Methodology I and II courses. The one-semester three credit course aims to enable students to acquire skills necessary for evaluating language teaching materials in current textbooks, adapting or developing materials for language teaching and language testing. The preservice teachers are expected to learn the approaches and techniques of material selection, evaluation, adaptation and development, acquire skills necessary for evaluating the course books and language teaching tasks in the textbooks and engage in material adaptation and design in language teaching.

It is generally expected that preservice instructional materials education courses address key areas of material related theory, philosophy, and practice as delineated by HEC policies and MNE standards regarding instructional materials. These documents serve as a basis for preservice instructional material course curriculum. However, despite the availability of these resources, there have been notably few studies that detail the content of instructional materials courses and that examine the integration of policies and standards within these courses. The current study aims to fill such a gap in literature.

\section{Selection of the Case Program}

We thought that it is essential to investigate the phenomenon in a particular case program so that it will be realistic and practical because our purpose was not search for what is common and pervasive in teacher education programs to make generalizations, but focus on understanding the alignment of the program in its complexity (Stake, 1988). Also, the concept of external alignment is a specific feature of individual programs. Different programs may have different profiles so evaluating the alignment of a group of EFL programs and then making a judgement about the EFL programs in the country is not logical nor realistic. Therefore, in order to be able to make sound decisions and precise judgments about the program alignment, a case study approach was prefered.

For the selection of the site, a purposeful sampling strategy was applied. The researchers purposefully selected to study the alignment of the EFL program at the specific university, which has attained remarkable achievements in university rankings. According to the English based Times Higher Education (THE), the university is the first and only Turkish university ranked among the top 100 universities in 2012, 2013 and 2014. Believing that the alignment profile of that university will reveal similar and useful implications for the universities in both national and international context, the researchers chose the specific program purposefully for this study.

\section{Data Sources}

Data sources used in this study were related to a) teacher education policy (i.e., Undergraduate EFL Teacher Education Program by HEC), b) standards for teacher practice (i.e., Generic Teacher Competence by MNE and Subject Specific Teacher Competences for English Language Teachers, MNE), and c) instructional material 
course curriculum from three different sections of the Materials Adaptation and Development course being offered by the case teacher eduction program.

Table 1

Data Sources

\begin{tabular}{lll}
\hline Policy & \multicolumn{1}{c}{ Standards } & \multicolumn{1}{c}{ Teacher Education } \\
\hline -Undergraduate EFL Teacher & -Generic Teacher Competences by & Syllabi of the Materials \\
Education Program by HEC & MNE (MEB, 2017) & Adaptation and Development \\
(YÖK, 2018) & -Subject Specific Teacher & Course (2017-2018 academic \\
& $\begin{array}{l}\text { Competences for English } \\
\text { Language Teachers by MNE } \\
\text { (MEB, 2008) }\end{array}$ & year) \\
& \\
\hline
\end{tabular}

We used the course syllabi as a valid source for understanding instructional materials education. After obtaining research ethics clearance, all three teacher educators giving the materials course were invited to participate in this study. The course instructors were contacted via email to request a copy of their most current preservice materials course syllabus. All of the three course syllabi were obtained from the course instructors. While syllabi differed in format, all maintained core components used for analysis including course descriptions and learning objectives. All course syllabi were assigned a generic, nonidentifiable ID code for analysis purposes to maintain faculty member anonymity.

Data from each policy, standard, and course syllabi were assigned an ID code prior to analysis. ID codes were generated for each policy statement, standard, course description, and learning objective based on its data source and data type (e.g., policy, standard, expectation).

\section{Data Analysis}

Document analysis. All policy, standards, and curricular learning objectives and descriptions were independently classified by two experts based on two alignment dimensions: categorical concurrence and depth of competence. Classification of data maintained a $90 \%$ agreement across the two experts, both of whom have $\mathrm{PhD}$ degree in Educational Sciences and have significant competence in qualitative research methods especially in content analysis. To determine categorical concurrence across data sources, each policy, standard, and syllabi component was deductively coded for its content area (Patton, 2002). This process for identifying categorical concurrence codes is different from other alignment methods, which seek to measure alignment to preestablished categories or anchors (e.g., Webb, 1997). Rather, our anchors were generated from across data sources to present a comprehensive listing of instructional material content areas found in policy, standards and course syllabi without giving preference to any one source. In total, 27 codes were initially identified, which we then thematically grouped into 7 content themes. The seven themes identified are 1) material integration, 2) appropriacy of materials to learners, 3) appropriacy of materials to teaching/learning context, 4) material types and features, 5) material variety, 6) electronic and digital materials and 7)the purpose of material use". See Appendix A for the coding criteria for competence areas.

Depth of competence was operationalized by classifying data by their level of complexity. The levels used in this phase reflect the level of work teachers are required to perform in order for the competence to be 
considered acceptable. The levels in this study describe the kind of action required starting from the simplest to the most complex cognitive process and behaviour. The coding process of the documents in terms of the depth level of competences was relatively straight forward because especially the standards and the learning objectives were stated mainly in the form of descriptors such as identify, be aware of, apply, use, find, evaluate, change, select etc. These descriptors had a good match with the descriptors in Porter's cognitive demand tool. The only difference was that the demands expected in the documents were placed on the demands of competences instead of cognitive demands. These competences with different demands helped the researchers develop the other dimension- the depth of competence- on the alignment matrix for this study.

Six depth levels were determined, each of which showed a higher demand of competence: 1)"knowledge", 2)“select", 3) "use", 4) "evaluate”, 5)“adapt" and 6)“design". Of the six competence levels, the first level "knowledge" refers to the core knowledges that every teacher or teacher candidate should have while the other five levels refer to the practices that teachers need to do in order to demonstrate their performance with instructional materials. Table 2 gives the depth levels and the descriptors in the documents.

Table 2

The Depth Levels of the Competences

\begin{tabular}{lll}
\hline \multicolumn{2}{l}{ Depth of Competence Levels } & \multicolumn{1}{c}{ Codes } \\
\hline Level 1: K & Knowledge & Know, be aware of, follow (i.e.,be knowledgable about) \\
Level 2: S & Selection & Find, choose, select \\
Level 3: U & Use & Employ, use, have, make use of, provide, enable students to use \\
Level 4: A & Adaptation & Adapt, add variety, change \\
Level 5: E & Evaluation & Analyze, evaluate, teach students how to evaluate \\
Level 6: D & Design & Design, develop, prepare \\
\hline
\end{tabular}

In the coding process, data may have been double coded if statement reflected more than one code. Based on coding of data across alignment dimensions, frequency tables were constructed to show the representation of the content congruence and depth of competence for each data source. Frequencies of codes were first generated for each course syllabus, policy document, and standard document independently, and then the frequencies of codes in policy and standard documents were counted together and transferred to the frequency table together as they indicate the external expectations. That is, the data sources were combined into two data sets for comparison: 1. explicit policies and standards for instructional materials competence; 2. teacher education curriculum for the preservice instructional materials education curricula.

Alignment analysis. After coding the data and transferring them to the frequency table, these data were processed for proportional quantification. This quantification process transforms the data counts into proportional values (DeLuca \& Bellara, 2013). The proportional value is calculated by dividing the number of codes for each competence area at each level by the total number of codes in the data set.

For example, in matrix x (See table 3), which shows the proportional values for standards and policies, cell A1 or $(1,1)$ (integratedness at knowledge level) has the proportional value " 0 ". This is calculated by dividing the number of codes in the cell "1", by "71" the total number of codes in the standards and policy documents. Thus, for the cell A1 $(1,1)$ the proportional value is $1 / 71=0,014$, which gives " 0 " when rounded off to one decimal. This is a measure of relative emphasis of the "integratedness" at the competence demand level of "knowledge" as compared to the total data counts for all the competences coded on this matrix. 
Tekir, Akar / The Current State of Instructional Materials Education: Aligning Policy, Standards, and Teacher Education ...

See table 3 for proportional values in policies and standards and table 4 for proportional values in teacher education curriculum.

Table 3

Matrix x for Policy and Standards Documents Showing Proportional Value

Policy and Standards Documents Depth of Competence

\begin{tabular}{|c|c|c|c|c|c|c|c|}
\hline Categorical concurrence & $\mathbf{K}$ & $\mathbf{S}$ & $\mathbf{U}$ & $\mathbf{E}$ & $\mathbf{A}$ & $\mathbf{D}$ & $\mathbf{T}$ \\
\hline Integratedness & 0 & 0 & 0 & 0 & 0 & 0 & 0 \\
\hline Appropriacy/contextualization to learner & 0 & .1 & .1 & 0 & 0 & .1 & .3 \\
\hline Appropriacy/contextualization to teaching/ learning context & 0 & 0 & 0 & 0 & 0 & 0 & 0 \\
\hline Material types and features & 0 & 0 & .1 & 0 & 0 & 0 & .1 \\
\hline Variety & 0 & 0 & .1 & 0 & 0 & 0 & .1 \\
\hline Electronic and digital materials & 0 & 0 & .1 & 0 & 0 & 0 & .1 \\
\hline Purpose of material use & 0 & 0 & .1 & 0 & 0 & .1 & .2 \\
\hline Total & 0 & .1 & .5 & 0 & 0 & .2 & 8 \\
\hline
\end{tabular}

Note. K: Knowledge, S: Select, U: Use, E: Evaluate, A: Adapt, D: Design, T: Total

Table 4

Matrix y for Teacher Education Curriculum Showing Proportional Value

\begin{tabular}{llllllll}
\hline & \multicolumn{7}{c}{$\begin{array}{c}\text { Policy and Standards Documents } \\
\text { Depth of Competence }\end{array}$} \\
\cline { 2 - 8 } Categorical concurrence & $\mathbf{K}$ & $\mathbf{S}$ & $\mathbf{U}$ & $\mathbf{E}$ & $\mathbf{A}$ & $\mathbf{D}$ & $\mathbf{T}$ \\
\hline Integratedness & 0 & 0 & 0 & 0 & 0 & 0 & 0 \\
Appropriacy/contextualization to learner & 0 & .1 & .1 & 0 & 0 & .1 & .3 \\
Appropriacy/contextualization to teaching/ & 0 & 0 & 0 & 0 & 0 & 0 & 0 \\
learning context & 0 & 0 & .1 & 0 & 0 & 0 & .1 \\
Material types and features & 0 & 0 & .1 & 0 & 0 & 0 & .1 \\
Variety & 0 & 0 & .1 & 0 & 0 & 0 & .1 \\
Electronic and digital materials & 0 & 0 & .1 & 0 & 0 & .1 & .2 \\
Purpose of material use & 0 & .1 & .5 & 0 & 0 & .2 & $\mathbf{8}$ \\
Total & 0
\end{tabular}

Note. K: Knowledge, S: Select, U: Use, E: Evaluate, A: Adapt, D: Design, T: Total

Table 5

Absolute discrepancies ( $x$-y) for Proportional Value of Each Code in Standards \& Policies and Teacher Education Curriculum

\begin{tabular}{|c|c|c|c|c|c|c|c|}
\hline \multirow{2}{*}{ Categorical concurrence } & \multicolumn{7}{|c|}{$\begin{array}{l}\text { Absolute Discrepancies } \\
\text { Depth of Competence }\end{array}$} \\
\hline & $\mathbf{K}$ & $\mathbf{S}$ & $\mathbf{U}$ & $\mathbf{E}$ & $\mathbf{A}$ & $\mathbf{D}$ & $\mathbf{T}$ \\
\hline Integratedness & 0 & 0 & 0 & .1 & 0 & 0 & .1 \\
\hline Appropriacy/contextualization to learners & 0 & .1 & .1 & 1 & .1 & .1 & .5 \\
\hline Appropriacy/contextualization to teaching/ learning context & 0 & 0 & 0 & .1 & 0 & 0 & .1 \\
\hline Material types and features & .1 & 0 & .1 & 0 & 0 & 0 & .2 \\
\hline Variety & 0 & 0 & .1 & 0 & 0 & 0 & .1 \\
\hline Electronic and digital materials & 0 & 0 & .1 & 0 & 0 & 0 & .1 \\
\hline Purpose of material use & 0 & 0 & .1 & .1 & .1 & .1 & .4 \\
\hline Total & .1 & .1 & .5 & .4 & .2 & .2 & 1.5 \\
\hline
\end{tabular}

Note: K: Knowledge, S:Select, U:Use, E: Evaluate, A: Adapt, D: Design, T: Total

The proportion-based process was used to moderate inflation of frequency counts from across the various sources as each had a different number of data pieces (DeLuca \& Bellara, 2013). 
After calculating the proportional values, a cell-by-cell comparison was made for each corresponding proportion from the cells of the two proportion matrices (matrix x and y). To calculate the Porter's alignment index, we need the total of absolute discrepancies between data sets $\left(\sum|x-y|\right)$. This value can be determined by getting the difference between the values of the two corresponding cells (Fulmer, 2011). For example, the proportional value in A4 $(1,4)$ (i.e., integratedness at evaluation level) in matrix $\mathrm{x}$ is 0 while the value in the same cell (A4) in matrix y is .1. Thus, on the absolute discrepancy table (See table 5), the absolute discrepancy value for the cell A4 is .1.

After getting the discrepancies, the alignment between these data sets was calculated using Porter's alignment index formula below (Porter, 2002). According to the formula, first the total discrepancy value was calculated by adding up the discrepancy values in each cell in table 4 . It is calculated as 1.5 . Then, the alignment formula was run, and the alignment index of the course curriculum to the standards and policy was found to be 0.25 .

Alignment $=1.0-\frac{\sum|x-y|}{2}$

Porter's Alignment Index $=1.0-\frac{1.5}{2}=0.25$

To explore if both sets of documents emphasize the same competence areas and depth level, the total proportional values in two alignment matrices were compared. The alignment decision was made based on this comparison. When the teacher education curriculum incorporated equal or higher proportional values than the policy and standards then it was considered to be aligned. If it placed less emphasis, then that particular competence area or depth level was considered as an area of misalignment.

\section{Findings}

Results from this study are presented following the order of analysis. First, we presented the code frequency tables for each alignment dimension by data source. Then, we analyzed the alignment of policies, standards, and curriculum components through a conjoint analysis of the matrices (table 3 and 4) showing the alignment dimensions.

\section{Analysis by Data Source}

Looking at table 6, which shows the frequencies and percentages of each competence content and depth level in both external documents (policy and standards) and teacher education curriculum, it is possible to claim that although the documents express competences on all categories in the table, some categories seem to be more focused. The most emphasized competences are the "appropriacy/ contextualization to learners" and "purpose of material use" as more than a fourth of the total competences are set on "appropriacy/ contextualization to learners", and about 20 percent of the competences are related to "purpose of material use". Competences related to "variety" and "electronic and digital materials" are represented in more than 15 percent of the documents. Following them is the competence area "material types and features" with more than eight 
percent representation. The slightest emphasis in the external documents is given to the competences related with "integratedness" and "appropriacy/ contextualization to context" both with less than five percent representation.

When it comes to the depth level of competences, it is possible to claim that more than 40 percent of the total competences are stated at the competence level "use", so it is by far the most emphasised level of competence. The competence levels "knowledge", "select" and "design" followed it with a nearly 15 percent representation. The least addressed competence levels are "evaluate" and "adapt" both with less than 10 percent representation.

When the teacher education curriculum is studied, it is possible to see that competences concerning "appropriacy/ contextualization to learners", "appropriacy/ contextualization to teaching/learning context" and "purpose of material use" are the most emphasized competence contents with more than 20 percent representation. "Material types and features" is among the most emphasised competence contents with more than 15 percent representation. The competence contents with the slightest emphasis are "integratedness", "variety" and "electronic and digital materials" with about 5 percent representation.

Table 6

Theme/Code Frequencies and Percentages in Policy and Standards and Teacher Education Curriculum.

\begin{tabular}{|c|c|c|c|c|c|c|c|c|c|c|c|c|c|c|c|}
\hline \multirow{3}{*}{$\begin{array}{l}\text { Categorical Data } \\
\text { Source } \\
\text { Concurrence }\end{array}$} & & \multicolumn{14}{|c|}{ Depth of Competence } \\
\hline & & \multicolumn{2}{|c|}{$\mathbf{K}$} & \multicolumn{2}{|c|}{$\mathbf{S}$} & \multicolumn{2}{|c|}{$\mathbf{U}$} & \multicolumn{2}{|c|}{$\mathbf{E}$} & \multicolumn{2}{|c|}{$\mathbf{A}$} & \multicolumn{2}{|c|}{ D } & \multicolumn{2}{|c|}{ Total } \\
\hline & & $f$ & $\%$ & $f$ & $\%$ & $f$ & $\%$ & f & $\%$ & $f$ & $\%$ & $f$ & $\%$ & $f$ & $\%$ \\
\hline \multirow{2}{*}{ Integratedness } & PS & 1 & 1.4 & 0 & 0 & 1 & 1.4 & 0 & 0 & 0 & 0 & 1 & 1.4 & 3 & 4.2 \\
\hline & $\mathrm{TE}$ & 0 & 0 & 0 & 0 & 0 & 0 & 7 & 5 & 0 & 0 & 1 & .7 & 8 & 5.7 \\
\hline \multirow{4}{*}{$\begin{array}{l}\text { Appropriacy } \\
\text { to learners } \\
\text { Appropriacy } \\
\text { to teaching/ } \\
\text { learning context }\end{array}$} & PS & 3 & 4.2 & 6 & 8.5 & 7 & 9.9 & 2 & 2.8 & 2 & 2.8 & 0 & 0 & 20 & 28.2 \\
\hline & $\mathrm{TE}$ & 0 & 0 & 6 & 4.3 & 0 & 0 & 13 & 9.2 & 7 & 5 & 5 & 3.5 & 31 & 22 \\
\hline & PS & 0 & 0 & 0 & 0 & 0 & 0 & 0 & 0 & 2 & 2.8 & 0 & 0 & 2 & 2.8 \\
\hline & $\mathrm{TE}$ & 3 & 2.1 & 6 & 4.3 & 0 & 0 & 11 & 7.8 & 6 & 4.3 & 4 & 2.8 & 30 & 21.3 \\
\hline \multirow{2}{*}{$\begin{array}{l}\text { Material types } \\
\text { and features }\end{array}$} & PS & 3 & 4.2 & 1 & 1.4 & 1 & 1.4 & 0 & 0 & 0 & 0 & 1 & 1.4 & 6 & 8.5 \\
\hline & $\mathrm{TE}$ & 9 & 6.4 & 6 & 4.3 & 2 & 1.4 & 1 & 0.7 & 5 & 3.5 & 3 & 2.1 & 26 & 18.4 \\
\hline \multirow{2}{*}{ Variety } & PS & 2 & 2.8 & 1 & 1.4 & 7 & 9.9 & 2 & 2.8 & 0 & 0 & 1 & 1.4 & 13 & 18.3 \\
\hline & $\mathrm{TE}$ & 0 & 0 & 1 & .7 & 0 & 0 & 5 & 3.5 & 1 & .7 & 1 & .7 & 8 & 5.7 \\
\hline \multirow{4}{*}{$\begin{array}{l}\text { Electronic and } \\
\text { digital materials } \\
\text { Purpose of } \\
\text { material use }\end{array}$} & PS & 2 & 2.8 & 1 & 1.4 & 5 & 7 & 2 & 2.8 & 0 & 0 & 1 & 1.4 & 11 & 15.5 \\
\hline & TE & 2 & 1.4 & 0 & 0 & 1 & .7 & 0 & 0 & 0 & 0 & 1 & .7 & 4 & 2.8 \\
\hline & PS & 0 & 0 & 1 & 1.4 & 8 & 11.3 & 0 & 0 & 1 & 1.4 & 6 & 8.5 & 16 & 22.5 \\
\hline & $\mathrm{TE}$ & 1 & .7 & 5 & 3.5 & 0 & 0 & 15 & 10.6 & 7 & 5 & 6 & 4.3 & 34 & 24.1 \\
\hline \multirow{2}{*}{ Total } & PS & 11 & 15.5 & 10 & 14.1 & 29 & 40.9 & 6 & 8.4 & 5 & 7 & 10 & 14.1 & 71 & 100 \\
\hline & $\mathrm{TE}$ & 15 & 10.6 & 24 & 17 & 3 & 2.1 & 52 & 36.9 & 26 & 18.4 & 21 & 14.9 & 141 & 100 \\
\hline
\end{tabular}

Note. K: Knowledge, S: Select, U: Use, E: Evaluate, A: Adapt, D: Design, PS: Policy and Standards Documents, TE: Teacher Education Curriculum, f: Frequency, \%: Percentage

In terms of levels of competences, more than a third of the competences are pronounced at the competence level "evaluate". Following it are the levels "adapt" and "select" with more than 15 percent representation. Depth level "design" is very close to them with nearly 15 percent representation. The "knowledge" level with about 10 percent representation, and "use" with about two percent representation are the least frequently stated competences in the teacher education curriculum.

To sum up, policy and standards documents and the teacher education curriculum express competences on almost all categories in the table; however, they seem to emphasize some categories more than the others. 


\section{Alignment across Data Sources}

The alignment index, which shows the alignment of the course curriculum to the standards and policies, was 0.25. The index suggests a weak alignment $(\mathrm{I}<0.5)$ (Porter, 2002) pointing to mismatches between policy and standards and the teacher education curriculum. To detect which competence area and level is responsible for the weak alignment, the proportional values of each competence area and depth level in matrix $\mathrm{x}$ and $\mathrm{y}$ were compared. If the teacher education curriculum incorporates higher proportional values than the policy and standards then it was considered to be aligned.

Based on the matrices (Table 3 and 4) showing the proportional values of the codes in each set of data source, several patterns of alignment and misalignment prevail. The overall trend reflects a greater alignment in the competence categories of "integratedness", "appropriacy to teaching/learning context", "material types and features" and "purpose of material use" as the teacher education curriculum has higher proportional values (PV: 3,2,3 respectively) on these competence categories than the policy and standard documents (PV: 1,1,2). The prevalence of teacher education curriculum related to these categories means that the program provides additional support for the development of teacher candidates' understandings of instructional materials in these areas.

Instances of misalignment were observed related to the competence areas of, "appropriacy to learner", "variety" and "electronic and digital materials". Policy, standards and curricula differed in their relative representation of these themes. "Appropriacy to learner" is identified by policy and standards slightly more than it is in the teacher education curriculum. It is mostly stated at select and use levels. Comparatively, "appropriacy to learner" is covered in teacher education curriculum at evaluate and adapt levels.

"Variety" was minimally addressed in course syllabi (5.7\%) but more fully covered by policy and standards documents (18.3\%), mostly at use level. The theme of "electronic and digital materials" showed a similar pattern with high representation of this theme in policy and standards documents (15.5\%) especially at use level. It was minimally covered in the course syllabus $(2.8 \%)$.

In terms of depth levels, the teacher education curriculum aligns to the policy and standards at "knowledge", "evaluate" and "adapt" levels while it misaligns at "use" "select" and "design" levels. The inadequate representation of these levels suggests that teacher education program fails to develop teacher candidates' skills of selecting, using and designing instructional materials to support their teaching.

These various points of misalignment may suggest different emphasis across data sources for teacher competence in instructional materials.

\section{Limitations}

While this research has resulted in important findings regarding the match among teacher education policy and standards, and teacher education practises in Turkey, there are limitations as well. Conclusions drawn regarding the alignment of teacher education to policy and standards in terms of instructional materials competence were based on course syllabi but not on curriculum implementation or student learning (Bowen, 2009; Goertz, 2006). Therefore, it is suggested that future research can include interviews with faculty members, 
observations of the course and sample student work. Also, it is important to recognize that findings from this study related to course syllabi are not generalizable beyond the institution that participated in this research. Other teacher education programs might have different intended outcomes and applications for instructional materials education, and thus may have different patterns of alignment.

\section{Discussion}

The purpose of this study was to examine the alignment between policies and standards and teacher education curriculum in terms of teacher competence in instructional materials. The central finding was that there were points of alignment and misalignments across data sources. A dominant trend in the alignment data was that course content was well matched to policy and standards in terms of "integratedness", "appropriacy/ contextualization to teaching/learning context", "material types and features" and "purpose of material use" and at "knowledge", "evaluate" and "adapt" levels. Across the data sets, the misalignment trend is evident for the content themes of "electronic and digital materials", "appropriacy/contextualization to learners" and "variety", and the depth levels of "use" and "design".

On the competence content "appropriacy/contextualization to learners" there seems to be poor alignment between data sets. Although both the teacher education curriculum and the policy and standards mention the significance of the competence in making instructional materials appropriate to learner, particularly to their language development, age, interests, daily life, language learning styles, needs, native culture and their experiences or realities in their lives, it has a higher proportional value in policy and standard documents. Also, in the policy and standards documents, teachers are expected to be able to "select", "use" and "design" materials appropriate to their learners while teacher educators seem to train teacher candidates to be able to "adapt" and "evaluate" materials to contextualize them to the learners. Şallı-Çopur (2008) had a similar finding in her program evaluation study. Most of the program graduates taking part in her study emphasized feeling competent in material adaptation. However, Coşkun and Daloğlu (2010) suggested that preservice teachers attending the same program feel competent not only in adapting but also designing and using materials.

In terms of the competence content "variety", there is especially more emphasis in the policy and standards at the competence level "use" than the teacher education curriculum. This means that teachers working in K-12 schools are expected to use materials to teach various discourse types (written, oral, formal, informal), use various texts (story, dialogue, letter etc.), and use language appropriately in various situations. This complies with McGrath's (2006) claim that students love variety; that is why, various tasks and texts and materials are to be employed in language education to break the boredom and foster student motivation.

We suggest that the teacher education program provides additional support to develop teacher candidates' competence in various materials as it emerged to be one of the areas that teachers need in their daily practice. Otherwise, the program will be regarded as comparatively inadequate as a change agent affecting the way new teachers are educated (Zeichner \& Gore, 1990). 
About the competence content "electronic and digital materials", the teacher education program seems to have minimal representation. This result is in line with what Şall-Çopur (2008) found in her evaluation study. She stated that nearly one fifth of the participants in her study indicated that they are incompetent or somewhat competent in making use of information technology (i.e., audio-visuals, electronic devices and computer). It is highly recommended that the teacher education program should have more representation for this competence area because MNE launched a digital project called Fatih Project (the Movement to Increase Opportunities and Technology), which aims to increase learning and teaching opportunities by using ICT tools and resources to address inadequacies in the learning and teaching processes for primary and secondary-education students (MEB EĞİTEK, 2002). To teach in classes equipped with LCD interactive smart boards and tablet PCs, preservice teachers will certainly need this competence.

When it comes to the depth levels of competences, policy and standard documents represent teacher competences in instructional materials mostly at "use" level, while they are highly represented at "knowledge", "select", "evaluate" and "adapt" levels in the teacher education curriculum. This suggests that teacher education policy makers would like to have EFL teachers with the ability to use the materials in the teaching context effectively while the teacher education program do not train pre-service teachers for that but mostly for higherlevel competences. The difference between the taught and the required competences is in line with the previous evaluation study done by Seferoğlu (2006), who pointed out a mismatch between what preservice teachers learn in the program and what they need in real classrooms.

Having mostly lower level competences may mean that teacher education policy and standards seem to consider teachers as passive technicians rather than reflective teachers who are producers of knowledge or problem-solvers (Kumaravadivelu, 2003). Contrarily, the teacher education program seems to train teacher candidates to be more reflective in their future professions. In that way, they are expected to be producers of knowledge offering solutions to the problems in their own setting rather than being passive consumers or transmitters of knowledge (Zeichner \& Liston, 1996). Consequently, the policy and standards documents seem to contradict the teacher education curriculum because the type of a prospective teacher aimed by the teacher education program is not in line with the teacher type MNE or HEC target.

The most striking mismatch between the teacher education curriculum and teacher education policy and standards is insufficient number of objectives and content on material use. However, material use is the basic skill that an EFL teacher may need in his/her future career, and the program seems to neglect such an important content, which may mean the education being given is not a very relevant to their future profession. The same result was highlighted by Şall1-Çopur (2008) in their program evaluation study.

Regarding this issue, it is advisable that the teacher education program should include more objectives and content to train prospective teachers on this competence. In order to be able to carry out more demanding tasks mentioned in the intended outcomes such as evaluation, adaptation and design, a language teacher should first be able to use a range of materials like books and paper, audio-visual material, laboratories, computers and so on. However, it is almost impossible to teach all these competences requiring different levels of demand from teacher candidates, so there seems to be a need for two different materials courses in the program. 
As the policy documents used in this research serve as guidelines for teacher education programs, this finding implies that teacher education programs should address these competences more fully in their program components either within or beyond their explicit instructional materials courses. Meeting policy and standards aims regarding teacher candidates' competence in instructional materials should not be reflected to a single course on materials but rather integrated across preservice program. Indeed, the duration of required instructional materials courses is short, typically one semester Three- hour course, leaving little instructional time to provide teacher candidates with a strong theoretical and practical foundation in instructional material use, selection, adaptation, evaluation and design. Therefore, we suggest to the teacher education program to offer two compulsory instructional materials courses, one as an introduction to the field that will focus on instructional materials literacy and lower level competences such as material selection and use and another that will focus on higher-level competences such as evaluation, adaptation and design of instructional materials. In this way, pre-service teachers can engage in deep and complex learning about the linkages between instructional materials and teaching, and learning.

To conclude, the results of the study indicate that there are conflicting messages given by various institutions influential in teacher education in Turkey. The points of misalignment between policy and practise is either because teacher education policy and standards and the teacher education curriculum do not emphasise the some competences or they emphasize the same competence but at different levels. About the emerging mismatches, the study suggests a two-way action plan to fill the gap between policy and practise. First, policy makers should revise the set of teacher competence standards. In this process, while the professional standards set by MNE and teacher education program content by HEC continue to represent core of instructional materials education given to teachers, they should be updated through consideration of recent literature and specific knowledge and skills required by teachers working in the current teaching context at K-12 schools. Additionally, they need to go beyond the technicist teacher education approach inherent in the policy documents, and should define the required competences.

Second, as the policy documents serve as benchmarks for teacher education programs in Turkey, the findings imply that teacher education programs should revise their programs and address the expected competences fully so that a greater alignment with the recent professional standards and teacher education policies will be promoted. In this way, all stakeholders; that is, policy makers, teacher recruiting body and teacher education programs will agree on the same key competences that a teacher should have, and there will be consistency in foreign language teacher education programs with the school needs. As a result, prospective teachers can be provided with appropriate and specialized training in instructional materials for their future professional practices.

To sum up, it is claimed that connectedness and coherence of teacher education programs with standards and policies are extremely important. Teacher education programs should be in line with the policy and standards. Programs that facilitate coherent learning experiences articulated within relevant frameworks of theory, policy and standards fortify for teacher candidates' fundamental educational conceptions and practices of teaching. This will also affect institutional accountability in the sense that degrees awarded by the institution meet standards set by the main teacher recruiting agency and policy maker. To do that, discrepancies at macro 
level policies and micro level teacher education practices should be remedied with a clear common vision and purpose and parallel changes in policy and practice should be made.

\section{References}

Anderson, L. W. (2002). Curricular alignment: A re-examination. Theory into Practice, 41(4), 255-260.

Biggs, J.B. (1999). Teaching for quality learning at university. Buckingham: Open University Press.

Bloom, B. (1956). Taxonomy of educational objectives: Handbook I: Cognitive domain. New York: Longman.

Britzman, D. P. (1990). Practice makes practice: A critical study of learning to teach. Albany: State University of New York Press.

Bowen, G. (2009). Document analysis as a qualitative research method. Qualitative Research Journal, 9(2), 27-40. http://dx.doi. org/10.3316/QRJ0902027

Bryk, A., Lee, V., \& Holland, P. (1993). Catholic schools and the common good. Cambridge, MA: Harvard University Press.

Caena, F. (2014). Literature Review: Teachers' Core Competences: Requirements and Development, Education and Training 2020 Thematic Working Group. Professional Development of Teachers. European Commission. Retrieved from http://ec.europa.eu/education/policy/strategic-framework/doc/teachercompetences_en.pdf

Coleman, J., Hoffer, T., \& Kilgore, S. (1982). High school achievement: Public, Catholic, and private schools compared. New York: Basic Books

Coşkun, A. \& Daloglu, A. (2010). Evaluating an English language teacher education program through Peacock's model. Australian Journal of Teacher Education, 35(6), 24-42. http://dx.doi. org/10.14221/ajte.2010v35n6.2

Cotton, K., \& Savard, W. G. (1982). Student discipline and motivation: Research synthesis. Portland, OR: Northwest Regional Educational Laboratory.

Darling-Hammond, L. (2000). Teacher quality and student achievement. Boston: American Educational Research Association.

Darling-Hammond, L. (2006). Constructing 21st-century teacher education. Journal of Teacher Education, 57(10), 1-15. http://dx.doi. org/10.1177/0022487105285962

DeLuca, C., \& Bellara, A. (2013). The current state of assessment education: Aligning policy, standards, and teacher education. Journal of Teacher Education, 64(4), 356-372. http://dx.doi. org/10.1177/0022487113488144

Drake, S. M., \& Burns, R. C. (2004). Meeting standards through integrated curriculum. Washington: ASCD. English, F. W. (1992). Deciding what to teach and test. Thousand Oaks, CA: Corwin Press.

Fuhrman, S. H. (1993). The politics of coherence. In S. H. Fuhrman (Eds.), Designing coherent education policy: Improving the system (pp. 1-34). San Francisco: Jossey-Bass. 
Tekir, Akar / The Current State of Instructional Materials Education: Aligning Policy, Standards, and Teacher Education ...

Fulmer, G. W. (2011). Estimating critical values for strength of alignment among curriculum, assessments, and instruction. Journal of Educational and Behavioural Statistics, 36(3), 381-402. http://dx.doi. org/10.3102/1076998610381397

Goertz, M. E. (2006). Policy analysis: Studying implementation. In J. Green, G. Camilli, \& P. Elmore (Eds.), Complementary methods for research in education (pp. 701-710). Washington, DC: American Education Research Association.

Grossman, P., Hammerness, K. M., McDonald, M., \& Ronfeldt, M. (2008). Constructing coherence structural predictors of perceptions of coherence in NYC teacher education programs. Journal of Teacher Education, 59(4), 273-287. http://dx.doi. org/ 10.1177/0022487108322127

Guyton, E., \& McIntyre, D. J. (1990). Student teaching and school experiences. In W. R. Houston (Eds.), Handbook of research on teacher education (pp. 514-535). New York: Macmillan.

Gürbüz, N. (2006). Differing perceptions of pre-service English teachers' strengths and weaknesses in the practicum: A case study in Turkey. ELTED, English Language Teacher Education and Development, 9(1), $39-46$.

Hammerness, K. (2012). Examining features of teacher education in Norway. Scandinavian Journal of Educational Research, 57(4), 1-20. http://dx.doi. org/10. 1080/00313831.2012.656285

Heggen, K., \& Terum, L. I. (2013). Coherence in professional education: Does it foster dedication and identification? Teaching in Higher Education, 18(6), 656-669. http://dx.doi. org/10.1080/13562517.2013.774352

Howey, K., \& Zimpher, N. (1989). Profiles of preservice teacher education. Albany: State University of New York.

Kizilaslan, I. (2011). ELT student teachers' competence for teaching language skills: A qualitative exploration. International Journal of Social Sciences and Humanity Studies, 3(1), 161-169.

Kitao, K., \& Kitao, K. (1997). Selecting and developing teaching/learning materials. The Internet TESL Journal, 4(4). Retrieved from http://iteslj.org/Articles/Kitao-Materials.html.

Kumaravadivelu, B. (2003). Beyond methods macro strategies for language teaching. New Haven: Yale University Press.

McGrath, I. (2002). Materials evaluation and design for language teaching. Edinburgh: Edinburgh University Press.

MEB. (2002). Öğretmen yeterlilikleri [Teacher Competences]. Ankara: Milli Eğitim Basımevi.

MEB. (2008). Öğretmenlik mesleği genel ve özel alan yeterlikleri [General and Specific Teacher Competences for Teaching Profession]. Ankara: Devlet Kitapları.

MEB. (2017). General competences for teaching profession. Retrieved from http://oygm.meb.gov.tr/meb_iys_ dosyalar/2018_06/29111119_TeachersGeneralCompetencies.pdf

MEB EĞİTEK. (2002). Çağı yakalama 2000 projesi, Milli Eğitim Bakanlığı, E- Dönüşüm [Catching up with the Era Project 2000, Ministry of National Education, E-Transformation]. Retrieved from http://www. ankarakoleji as.com.tr/milliegitim.htm.

Newmann, F. M., Smith, B., Allensworth, E., \& Bryk, A. S. (2001). Instructional program coherence: What it is and why it should guide school improvement policy. Educational Evaluation and Policy Analysis, 23(4), 297-321. 
Patton, M. Q. (2002). Qualitative research and evaluation methods ( $3^{\text {rd }}$ ed.). Thousand Oaks, CA: SAGE.

Porter, A. C. (2002). Measuring the content of instruction: Uses in research and practice. Educational Researcher, 31(7), 3-14.

Russell, T., McPherson, S., \& Martin, A. K. (2001). Coherence and collaboration in teacher education reform. Canadian Journal of Education, 26(1), 37-55.

Sali, P., \& Kecik, I. (2018). Challenges of First Years of Teaching in Turkey: Voices of Novice EFL Teachers English Language Teaching. English Language Teaching, 11(4), 117-131.

Seferoglu, G. (2006). Teacher candidates' reflections on some components of a pre-service English teacher education programme in Turkey. Journal of Education for Teaching, 32(2), 369-378.

Shulman, L.S. (1987). Knowledge and teaching: Foundations of the new reform. Harvard Educational Review, 57(1), 1-22.

Smith, M. S., \& O’Day, J.A. (1991). Systemic School Reform. In S. H. Fuhrman and B. Malen (Eds), The Politics of Curriculum and Testing: Politics of Education Association Yearbook (pp. 233-267). Bristol: Falmer Press.

Stake, R.E. (1988). Case study methods in educational research: Seeking sweet water. In R.M.Jaeger (Eds.), Complementary methods for research in education (pp. 253-278). Washington, DC: American Educational Research Association.

Şall1-Çopur, D. (2008). Teacher effectiveness in initial years of service: A case study on the graduates of METU foreign language education program (Unpublished doctoral dissertation, Middle East Technical University, Ankara, Turkey). Retrieved from https://tez.yok.gov.tr/UlusalTezMerkezi/

Tatto, M. T. (1996). Examining values and beliefs about teaching diverse students: Understanding the challenges for teacher education. Educational Evaluation and Policy Analysis, 18(2), 155-180.

YÖK. (2005). Ögretmen egitiminde standardlar ve akreditasyon [Standards and acreditation in teacher education]. Retrieved from www.yok.gov.tr/egitim/ ogretmen/ ogretmen_egitiminde_standartlar_ve_ akreditasyon.htm

YÖK. (2018). Yeni öğretmen yetiştirme lisans programlart: Yüksek Öğretim Kurulu Baskanlığı. [New undergraduate programs for teacher education: Higher Education Council] Retrieved from http://www.yok.gov.tr/web/guest/icerik/-/journal_content/56_INSTANCE_rEHF8BIsfYRx/ $10279 / 41807946$

Webb, N. L. (1997). Criteria for alignment of expectations and assessments in mathematics and science education. Washington, DC: Council of Chief State School Officers.

Zeichner, K., \& Gore, J. (1990). Teacher socialization. In W. Robert Houston (Eds.), Handbook of research on teacher education (pp.329-348). New York: Macmillan.

Zeichner, K. M. \& Liston, D. P. (1996). Reflective teaching: An introduction. New Jersey: Lawrence Erlbaum Associates, Publishers.

Zeichner, K., \& Tabachnik, B. R. (1981). Are the effects of university teacher education "washed out" by school experience? Journal of Teacher Education, 32(3), 7-11. http://dx.doi. org/10.1177/002248718103200302 